UDC 504.06

Vasyl M. Trysnyuk, Dr. Sc. (Tech)

ORCID 0000-0001-9920-4879, e-mail: trysnyuk@ukr.net

Viktor O. Shumeiko, $\mathrm{PhD}$ (Tech)

ORCID 0000-0002-0285-4566,e-mail: shym1983@ukr.net

Yuriy M. Holowan, graduate student

ORCID 0000-0001-7050-9310,e-mail: dirrecta@gmail.com

Institute of Telecommunications and Global Information Space of NASU, Kyiv, Ukraine

\title{
MECHANISM TO DETERMINE QUANTITATIVELY CHARACTERIZE THE LEVEL OF CONCENTRATION OF POLLUTANTS EMISSIONS ROAD TRANSPORT
}

\begin{abstract}
Summary. The basic mechanisms of pollution of the surface atmosphere and upper soil layer emission car transport roadside strip. Road transport, together with heavy industry, is one of the main air pollutants. Exhaust gases, crankcase gases, smoke, soot lead to complex chemical reactions in the surface layer of the atmosphere. Presented a number of methods to assess the level of contamination, analyses their strengths and weaknesses. Considered methodology issuance previous forecast spread of contamination including disturbing factors and their impact on the concentration of contaminants, as well as mathematical tools to determine the quantitative characteristics of concentration levels pollutants substances. The developed methodology is one of the ways to issue a preliminary forecast of the spread of pollution, taking into account disturbing factors in the presence of a priori data. This methodology takes into account a set of factors influencing the level of pollution concentration and the empirically obtained functional dependences of the influence of each of the disturbing components on the level of pollution. The constructed model of interaction of the established factors in the form of the graph of interaction characterizes causal relations.
\end{abstract}

Keywords: landscapes by element maps; geoecological ground; ecosystem; background content

\section{В.М. Триснюк, В.О. Шумейко, Ю.М. Голован}

Інститут телекомунікацій і глобального інформаційного простору НАН України, м. Київ, Україна

\section{МЕХАНІЗМ ВИЗНАЧЕННЯ КІЛЬКІСНИХ ХАРАКТЕРИСТИК РІВНЯ КОНЦЕНТРАЦЇ ЗАБРУДНЮЮЧИХ РЕЧОВИН ВИКИДАМИ АВТОМОБІЛЬНОГО ТРАНСПОРТУ}

Анотація. Проаналізовано основні механізми забруднення приземного шару
атмосфери $і$ верхнього трунтового шару викидами автомобільного
транспорту у придорожній смузі. Автомобільний транспорт разом із
важкою промисловістю відноситься до основних забруднювачів атмосфери.
Відпрацьовані гази, картерні гази, дими, сажа призводять до складних
хімічних реакцій в приземному шарі атмосфери. Наведено рядметодів оцінки
рівня забруднення, проаналізовано їх сильні та слабкі місия. Розглянтта
методологія видачі попереднього прогнозу розповююдення забруднення

(C) В.М. Триснюк, В.О. Шумейко, Ю.М. Голован, 2021

ISSN: 2411-4049. Екологічна безпека та природокористування, № 2 (38), 2021 
з урахуванням збурюючих чинників та їх впливу на рівень концентрації забруднень, а також математичний апарат для визначення кількісних характеристик рівня концентрації забруднюючих речовин. Розроблена методологія $\epsilon$ одним зі способів видачі попереднього прогнозу розповсюдження забруднень з урахуванням збурюючих чинників за наявності апріорних даних. В даній методології враховуються сукупність чинників впливу на рівень концентраиії забруднень $і$ отримані емпіричним шляхом функиіональні залежності впливу кожної зі збурюючих складових на рівень забруднення. Побудована модель взаємодії встановлених чинників у вигляді графа взаємодії характеризує причинно-наслідкові відносини.

Ключові слова: ландшафти; поелементні карти; геоекологічний полігон; екосистема; фоновий вміст

DOI: $10.32347 / 2411-4049.2021 .2 .79-93$

\section{Постановка проблеми}

Проблема забруднення довкілля викидами автомобільного транспорту залишається надзвичайно актуальною протягом вже достатньо довгого часу, і в майбутньому іiі актуальність буде тільки зростати. Масштаби забруднення збільшуються пропорційно до темпів автомобілізації суспільства. Найбільш негативні наслідки автотранспортне забруднення складає для територій, що знаходяться поблизу основних автошляхів. В рамках таких придорожніх смуг концентрація шкідливих речовин може перевищувати ГДК в декілька разів. Вплив транспортних викидів відчувається на відстані 1-2 км від автодороги та розповсюджується на висоту близько 300 м.

Поточна ситуація потребує розробки і впровадження комплексу методів кількісної оцінки масштабу забруднень конкретної ділянки придорожньої смуги. Масштаби та специфіка забруднення залежать від низки чинників: завантаженості автодороги, типу транспорту, який є переважним на даній ділянці (маються на увазі перш за все технічні характеристики двигуна внутрішнього згоряння), рельєфу місцевості, поточних метеорологічних умов та загальної характеристики клімату, наявності та параметрів захисних лісосмуг тощо. Також проблема потребує розробки математично обгрунтованої методики прогнозування розподілу викидів в рамках придорожньої смуги.

Аналіз останніх досліджень. Проблеми моделювання забруднення земель вздовж автомобільних доріг, на чому грунтуються екологічний аудит, екологічний моніторинг та екологічна безпека, розглянуті в багатьох опублікованих роботах. Для України велике значення щодо висвітлення проблем екологічної оцінки мають праці О.M. Трофимчука [1], О.С. Бутенко [7], I.М. Волошина [2], О.М. Адаменка [3], В.М. Гуцуляка [4] та багатьох інших дослідників.

Метою роботи $\epsilon$ дослідження впливу забруднення земель вздовж автомобільних доріг за допомогою комп'ютерно-картографічного моделювання та побудови поелементних еколого-техногеохімічних карт.

\section{Виклад основного матеріалу}

В першу чергу необхідно провести аналіз основних чинників і компонентів забруднення.

Спектр хімічних речовин, що виділяються під час руху автотранспорту, є достатньо широким. Їх можна поділити на дві великі категорії. Перша група 
токсичних речовин пов'язана 3 хімічними реакціями окислення палива, що протікають як в період перед згорянням, так і в процесі згоряння. Друга група токсичних речовин утворюється при з'єднанні азоту і надмірного кисню в продуктах згоряння.

Під час роботи двигуна внутрішнього згоряння джерелами викидів шкідливих речовин є відпрацьовані гази (далі - ВГ), картерні гази та продукти випаровування із системи живлення. Серед цих джерел основним є ВГ, які мають складний хімічний склад: більше 1000 різних шкідливих речовин, які чинять негативний вплив на довкілля, і лише 2003 них розпізнано. Основними $€$ : оксид вуглецю $\mathrm{CO}$, вуглеводні (загальна формула $\mathrm{C}_{\mathrm{x}} \mathrm{H}_{\mathrm{y}}$ ), оксиди азоту (NO), канцерогенні речовини, до яких належать складні ароматичні вуглеводні поліциклічної будови (найпоширенішим є бенз(а)пірен $\mathrm{C}_{20} \mathrm{H}_{12}$ ), альдегіди (RHCO), сполуки свинцю $\left(\mathrm{PbO}_{4}\right)$ i сажа (C). В картерних газах i випаровуваннях містяться, в основному, вуглеводні $[4,7,8]$.

Процентний розподіл між трьома джерелами шкідливих викидів характеризується в табл. 1.

Таблиця 1 - Процентний розподіл між трьома джерелами шкідливих викидів

\begin{tabular}{|l|c|c|c|}
\hline & $\mathbf{C O}$ & $\mathbf{C}_{\mathbf{x}} \mathbf{H}_{\mathbf{y}}$ & $\mathbf{N O}_{\mathbf{x}}$ \\
\hline Відпрацьовані гази & 100 & 55 & 100 \\
\hline Картерні гази & - & 25 & - \\
\hline Випаровування палива & - & 20 & - \\
\hline
\end{tabular}

Також рух автотранспорту призводить до відкладення сполук важких металів. Важкі метали відкладаються в придорожніх смугах як в результаті роботи власне автотранспортних засобів, так і при стиранні полотна дороги. В результаті стирання автомобільних шин в грунті поблизу автодороги осідають такі елементи, як алюміній, кобальт, мідь, залізо, цинк, кадмій, свинець та ін. Первинну їх дію відчувають рослинні організми.

Бензинові та дизельні ДВ3 мають свої переваги та недоліки в контексті забруднення навколишнього середовища. Гранично допустима концентрація шкідливих речовин у складі їх ВГ також різниться (табл. 2).

Таблиця 2 - ГДК шкідливих речовин у складі ВГ для двигунів двох основних категорій

\begin{tabular}{|c|c|c|}
\hline Назва речовини & Бензинові & Дизелі \\
\hline Оксид вуглецю (СО), \% & 10 & 0,3 \\
\hline Вуглеводні (СхНу), \% & 2 & 0,5 \\
\hline Оксиди азоту (NOx), \% & 0,6 & 0,2 \\
\hline Альдегіди (RCHO), \% & 0,2 & 0,05 \\
\hline 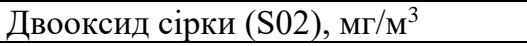 & 0,003 & 0,015 \\
\hline Сажа, мг/м ${ }^{3}$ & 100 & 2000 \\
\hline 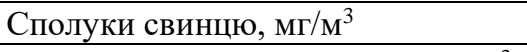 & 60 & 0 \\
\hline Канцерогени (бенз(а)пірен), мг/м ${ }^{3}$ & 25 & 10 \\
\hline
\end{tabular}

Як бачимо, викиди основних забруднюючих речовин значно нижче в дизельних ДВЗ. Проте вони відрізняються підвищеними викидами сажі, що утворюється унаслідок перевантаження палива. Сажа насичена 
канцерогенними вуглеводнями і мікроелементами; їх викиди в атмосферу неприпустимі $[9,10,11]$.

Використання дизелю дає можливість запобігти викидам в атмосферу сполук свинцю. Але цьому можна запобігти i в разі невикористання етильованого палива у бензинових ДВЗ.

Також масштаб та характер забруднення залежить від швидкості руху автомобіля. Ця залежність має непрямий характер. Відомо, що найбільш забрудненими є центральні вулиці великих міст. Це трапляється не лише 3 причини високого рівня автомобілізації на даних автошляхах, а й з тієї причини, що при автомобільних «пробках» та великій кількості світлофорів двигун багато часу проводить на холостому ході, що призводить до надзвичайно великих викидів.

До того ж спрацьовує ряд інших чинників, що впливають па режим руху автомобіля. Це, наприклад, рельєф місцевості та якість покриття автодороги. Ідеальним є постійний рух зі швидкістю 60 км/год, відповідно, покриття низької якості та розчленований рельєф (наприклад, гірський) є додатковими чинниками, що збільшують забруднення (при гальмуванні та прискоренні, чергування яких за таких умов є постійним, загальний об'єм викидів зростає у 8 разів) [12].

Викиди автотранспорту розподіляються в основному в приземному шарі атмосфери, а також в зоні аерації грунтового покриву. Розглянемо механізми цього розподілу.

Автомобільний транспорт разом із важкою промисловістю відноситься до основних забруднювачів атмосфери. Відпрацьовані гази, картерні гази, дими, сажа призводять до складних хімічних реакцій в приземному шарі атмосфери. Результатом таких реакцій є синтез небезпечних для екосистеми речовин, таких як озон, утворення фотохімічного смогу, підвищення середньої температури повітря, що призводить до появи «парникового ефекту». Автомобільні викиди розповсюджуються і трансформуються в атмосфері за певними закономірностями. Так, тверді частинки розміром більше 0,1 мм осідають на підстилаючих поверхнях (в основному через дію гравітаційних сил) і забруднюють грунтовий покрив. Частинки, розмір яких менше 0,1 мм, а також газові домішки у вигляді $\mathrm{CO}, \mathrm{C}_{\mathrm{x}} \mathrm{H}_{\mathrm{y}}, \mathrm{NO}_{\mathrm{x}}, \mathrm{SO}_{\mathrm{x}}$ розповсюджуються в атмосфері під впливом процесів дифузії. Вони вступають в процеси фізикохімічної взаємодії між собою і з компонентами атмосфери, і їх дія виявляється на локальних територіях в межах певних регіонів [9].

Ступінь забруднення атмосферного повітря викидами автотранспорту залежить від можливості перенесення даних забруднюючих речовин на значні відстані, рівня їх хімічної активності, метеорологічних умов розповсюдження.

Компоненти шкідливих викидів 3 підвищеною реактивною здатністю, потрапляючи у вільну атмосферу, взаємодіють між собою і компонентами атмосферного повітря. При цьому розрізняють фізичну, хімічну і фотохімічну взаємодії.

Приклади фізичного реагування: конденсація пари кислот у вологому повітрі 3 утворенням аерозолю, зменшення розмірів крапель рідини в результаті випаровування в сухому теплому повітрі. Рідкі і тверді частинки можуть об'єднуватися, адсорбувати або розчиняти газоподібні речовини.

Реакції синтезу і розпаду, окислення і відновлення здійснюються між газоподібними компонентами забруднюючих речовин і атмосферним повітрям. 
Деякі процеси хімічних перетворень починаються безпосередньо 3 моменту надходження викидів в атмосферу, інші - при появі для цього сприятливих умов - необхідних реагентів, сонячного випромінювання, інших чинників.

При виконанні транспортної роботи істотним є викид з'єднань вуглецю у наступному вигляді: $\mathrm{CO}$ (може окислюватися до $\mathrm{CO}_{2}$, за наявності домішок до сильних окислювачів $\left(\mathrm{O}, \mathrm{O}_{3}\right)$, перекисних з'єднань і вільних радикалів); $\mathrm{C}_{\mathrm{x}} \mathrm{H}_{\mathrm{y}}$ (в результаті утворюються перекиси, вільні радикали, з'єднання і оксиди азоту і сірки) [6].

З'єднання азоту, що потрапляють в атмосферу від об'єктів автотранспортного комплексу, представлені в основному $\mathrm{NO}$ i NO 2 . Моноксид азоту, що виділяється в атмосферу під впливом сонячного світла, інтенсивно окислюється атмосферним киснем до діоксиду азоту. Кінетика подальших перетворень діоксиду азоту визначається його здатністю поглинати ультрафіолетові промені і дисоціювати на моноксид азоту та атомарний кисень в процесах фотохімічного смогу.

Значна частка викидів розподіляється також в грунтах. Негативна дія автомобільного транспорту на грунтовий покрив придорожньої смуги визначається надходженням в грунт найрізноманітніших хімічних речовин, серед яких важким металам i, перш за все, свинцю і його з'єднанням в численних дослідженнях приділялася найбільш пильна увага. Проте проблема забруднення свинцем придорожнього грунтового покриву стає все менш актуальною. В той же час все більш гостро виявляється проблема забруднення грунтів нафтопродуктами, бенз(а)піреном, з'єднаннями цинку і деяких інших важких металів $[15,16]$.

Підвищений вміст цинку став характерним явищем, яке через свою екологічну небезпеку вимагає пильного контролю і уважного вивчення.

Цинк поступає в придорожній простір в результаті стирання різних деталей, ерозії оцинкованих поверхонь, зносу шин, за рахунок використання в маслах присадок, що містять цей метал. Масова частка цинку в моторних маслах для бензинових двигунів складає 0,09-0,12\%, у маслах для дизельних двигунів $0,05-0,1 \%$.

Після відмови від використання з'єднань кадмію в процесах вулканізації гуми і заміни їх з'єднаннями цинку стирання автомобільних шин також стало одним 3 джерел накопичення цього металу уздовж дороги. В результаті цих процесів уздовж автомобільних доріг формуються геохімічні аномалії цинку. На жаль, методологія розрахунків накопичення цинку в придорожніх грунтах поки не розроблена, процеси міграції і накопичення цинку, що відбуваються в грунті, недостатньо вивчені, що не дозволяє упевнено прогнозувати процеси його розподілу в грунті.

Отримані дані показують, що проблема забруднення придорожніх грунтів цинком починає виявлятися все більш виразно. Тоді як численні вимірювання демонструють успіхи в боротьбі зі свинцевим забрудненням, небезпека накопичення в придорожніх грунтах неприпустимої кількості цинку наростає.

Нафтопродукти, що є композицією найрізноманітніших вуглеводнів, є, як загальновідомо, найбуденнішим і повсюдним забруднювачем придорожніх смуг. Незважаючи на те, що забруднення ними носить наймасштабніший i найпоширеніший характер, яких-небудь задовільних методик, що забезпечують прогнозні оцінки забруднення грунтів, до сьогодні не розроблено. 
Серед показників, що характеризують забруднення грунту вуглеводнями, особливо значущим є бенз(а)пірен, що має канцерогенну дію. Бенз(а)пірен у складі інших поліциклічних ароматичних вуглеводнів міститься у відпрацьованих газах автомобільних двигунів [17].

Дослідження, що присвячені вмісту шкідливих речовин в грунтовому покриві, на сьогоднішній день $є$ необхідними з багатьох причин. Специфіка хімічного складу грунту впливає на сільськогосподарські властивості грунтів придорожньої смуги. Знати їі необхідно для оптимізації сільськогосподарської діяльності в придорожній смузі. Наприклад, деякі сільськогосподарські культури є більш стійкими до забруднення важкими металами. Також це питання набуває величезної актуальності в контексті грошової оцінки земельних ресурсів.

Оцінка характеру та масштабів забруднення навколишнього середовища викидами автотранспорту може бути виконана за допомогою комплексу методів, що враховують всі аспекти забруднення. Надзвичайно складно привести численні дані до єдиного інтегрального показника, який показував би рівень забруднення довкілля. Оскільки ми розглядаємо забруднення територій уздовж автошляхів, стан водоймищ в даному випадку не $\epsilon$ принциповим, тому зупинимось докладніше на розрахунках забруднення повітря та грунтового покриву [18].

При забрудненні повітряного середовища слід виходити 3 ситуації, що склалася, враховуючи фоновий рівень забруднення, існуючі локальні джерела забруднення і перспективи їх зміни на прогнозний період. На основі цих даних можливе проведення осмислених оцінок, що дозволяють визначити внесок нового об'єкта (в даному випадку - автомобільної дороги) в забруднення атмосфери та порядок виконання необхідних природоохоронних заходів. У зв'язку 3 цим необхідно розглянути питання, пов'язані 3 фоновими концентраціями забруднюючих речовин, з оцінкою дії руху і з загальними діями при експлуатації дороги, виходячи з розглянутих природно-кліматичних умов на прогнозний період [7].

Забруднення атмосферного повітря відпрацьованими газами автомобілів зручно оцінювати за концентрацією оксиду вуглецю (мг/мі) за формулою:

$$
K_{c o}=0,5+0,01 \times N \times K_{m} \times K_{a} \times K_{y} \times K_{c} \times K_{\text {в }} \times K_{n},
$$

де 0,5 - фонове забруднення атмосферного повітря нетранспортного походження, мг/мі; $N$ - сумарна інтенсивність руху автомобілів на міській дорозі, автомобілів в годину; $K_{n}-$ коефіцієнт, що залежить від типу транспортного засобу; $K_{a}$ - коефіцієнт, що враховує аерацію місцевості; $K_{y}-$ коефіцієнт, що враховує зміну забруднення атмосферного повітря залежно від величини поздовжнього ухилу; $K_{c}$ - коефіцієнт, що враховує зміну концентрації СО залежно від швидкості вітру; $K_{\text {в }}$ - коефіцієнт відносної вологості повітря; $K_{m}$ - коефіцієнт токсичності автомобілів по викидах в атмосферне повітря оксиду вуглецю.

Коефіцієнт токсичності автомобілів визначається як середньозважений для потоку автомобілів за формулою: 


$$
\begin{gathered}
\sim 85 \sim \\
K_{m}=P_{i} \times K_{3},
\end{gathered}
$$

де $P_{\text {i }}$ - склад руху в долях одиниць; $K_{3}$ - коефіцієнт збільшення забруднення атмосферного повітря СО на перехрестях.

Нижче в таблицях наведені величини відповідних коефіцієнтів в залежності від конкретних параметрів місцевості.

\section{Таблиця 3 - Значення Kn}

\begin{tabular}{|l|c|}
\hline \multicolumn{1}{|c|}{ Тип автомобіля } & Kn \\
\hline Середній вантажний & 2,9 \\
\hline Автобус & 3,7 \\
\hline Легкий вантажний & 2,3 \\
\hline Важкий вантажний (диз.) & 0,2 \\
\hline Легковий & 1,0 \\
\hline
\end{tabular}

Таблиця 4 - Значення $K a$

\begin{tabular}{|l|c|}
\hline \multicolumn{1}{|c|}{ Тип місцевості за ступенем аерації } & $\boldsymbol{K a}$ \\
\hline Транспортні тонелі & 2,7 \\
\hline Транспортні галереї & 1,5 \\
\hline $\begin{array}{l}\text { Магістральні вулиці та дороги з багатоповерховою } \\
\text { забудовою з 2 боків }\end{array}$ & 1,0 \\
\hline $\begin{array}{l}\text { Житлові вулиці з одноповерховою забудовою, вулиці та } \\
\text { дороги у виємці }\end{array}$ & 0,6 \\
\hline $\begin{array}{l}\text { Міські вулиці та дороги з одноповерховою забудовою, } \\
\text { набережні, естакади, віадуки, високі насипи }\end{array}$ & 0,4 \\
\hline
\end{tabular}

Таблиця 5 - Значення Кв

\begin{tabular}{|c|c|}
\hline Відносна вологість, $\%$ & $\boldsymbol{K} \boldsymbol{}$ \\
\hline 100 & 1,45 \\
\hline 90 & 1,30 \\
\hline 80 & 1,15 \\
\hline 70 & 1,00 \\
\hline 60 & 0,85 \\
\hline 50 & 0,75 \\
\hline 40 & 0,60 \\
\hline
\end{tabular}

Таблиця 7 - Значення $K c$

\begin{tabular}{|c|c|}
\hline Швидкість вітру & $\boldsymbol{K} \boldsymbol{c}$ \\
\hline 1 & 2,70 \\
\hline 2 & 2,00 \\
\hline 3 & 1,50 \\
\hline 4 & 1,20 \\
\hline 5 & 1,05 \\
\hline 6 & 1,00 \\
\hline
\end{tabular}

Таблиця 6 - Значення Ky

\begin{tabular}{|c|c|}
\hline Поздовжній ухил & $\boldsymbol{K y}$ \\
\hline 0 & 1,00 \\
\hline 2 & 1,06 \\
\hline 4 & 1,07 \\
\hline 6 & 1,18 \\
\hline 8 & 1,55 \\
\hline
\end{tabular}

Таблиця 8 - Значення Кз

\begin{tabular}{|l|c|}
\hline \multicolumn{1}{|c|}{ Тип перехрестя } & К3 \\
\hline Перехрестя, що регулюється: & \\
\hline світлофорами звичайне & 1,8 \\
\hline світлофорами кероване & 2,1 \\
\hline саморегульоване & 2,0 \\
\hline Нерегульоване: & \\
\hline зі зниженням швидкості & 1,9 \\
\hline кільцеве & 2,2 \\
\hline 3 обов'язковою зупинкою & 3,0 \\
\hline
\end{tabular}


Згідно $з$ використовуваною раніше методикою розрахунку забруднення грунту кількість забруднюючої речовини визначалася, виходячи з пропозиції, що всі викиди розподіляються упоперек дороги відповідно до нормального закону розподілу:

$$
p(x)=\frac{1}{\sigma \sqrt{2 \pi}} e^{\frac{-(x-\mu)^{2}}{2 \sigma^{2}}}
$$

де $\sigma=60$.

Додатково враховувався факт наявності і класифікації лісонасаджень (залежність показана на рис. 1).

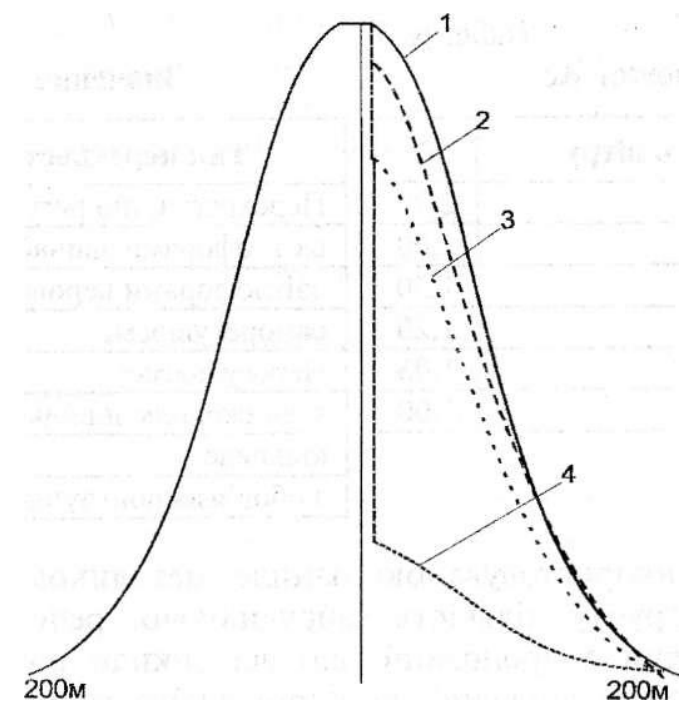

Рис. 1 - Розподіл забруднення уздовж дороги: 1 - лісосмуги немає; 2 - смуга чагарника; 3 - смуга дерев; 4 - зелений масив

Така методика розрахунку не дає можливості адекватно розрахувати концентрацію забруднень в реальних умовах, оскільки не враховується ряд збурюючих чинників.

Так само класичним варіантом підрахунку рівня забруднень є метод, заснований на використанні насамперед статистичних матеріалів, що стосуються завантаженості автошляхів, даних про найбільш розповсюджені типи автотранспорту (відповідно до цього детермінують найбільш уживаний тип палива). Похибка розрахунків напряму залежить від якості даних, в ідеальних умовах потрібні навіть дані про марки автотранспортних засобів. Велика увага приділяється кореляції характеру забруднення з характеристиками клімату території та конкретними метеорологічними умовами (середні температури, їх добова амплітуда, річна кількість опадів, переважний напрям вітру в залежності від сезону тощо). Необхідними також є вихідні емпіричні дані про стан грунтового покриву (щільність грунту, товщина грунтового шару, в якому можуть розташовуватися з'єднання свинцю) [8].

Потужність емісій свинцю за даної середньодобової інтенсивності руху автотранспорту визначається за формулою:

$$
P_{e}=K_{n} \times K_{o} \times K_{m} \times \sum\left(G_{i} \times P_{i} \times N_{i}\right),
$$


де $P_{e}-$ визначається в мг/мі на добу; $K_{n}=0,74-$ коефіцієнт перерахунку одиниць виміру; $K_{o}=0,8$ - коефіцієнт, що враховує осідання свинцю в системі випуску відпрацьованих газів; $K_{m}=0,8$ - коефіцієнт, що враховує частку викидів свинцю у вигляді твердих елементів в загальному об'ємі викидів; $G_{i}-$ середні експлуатаційні витрати палива для відповідної моделі автотранспорту; $N_{i}$ - середньодобова інтенсивність руху автотранспорту вибраної моделі; $P_{i}-$ вміст добавки свинцю в паливі, що застосовується на автомобілі обраного типу.

Рівень забруднення свинцем поверхневого грунтового шару на різних відстанях від автодороги визначається за формулою:

$$
P_{c}=\frac{P_{n}}{h \times \rho},
$$

де $P_{c}$ - рівень забруднення грунту з'єднаннями свинцю, мг/кг; $h$ - товщина грунтового шару (в метрах), в якому розташовуються викиди свинцю, для орних земель приймається за 0,2 м; $\rho$ - щільність грунту; $P_{n}$ - відклади свинцю на поверхні землі (мг/м³), величина яких визначається за формулою:

$$
P_{n}=0,4 K_{1} \times U_{v} \times T_{p} \times P_{e},
$$

де $K_{1}$ - коефіцієнт, що враховує відстань від автодороги; $U_{v}-$ коефіцієнт, що залежить від сили та напряму вітру, приймається як рівний відношенню площі рози вітрів з боку дороги, протилежного досліджуваній зоні, до загальної площі; $T_{p}$ - розрахунковий строк експлуатації дороги в добах, приймається за 7300 діб, що відповідає 20-річному прогнозному строку; $P_{e}$ - потужність емісії свинцю.

Переваги цього методу перед розглянутим раніше полягають саме в більш детальному аналізі статистичних даних, що стосуються транспортних засобів, оскільки, як доведено вище, характеристики забруднення суттєво різняться в залежності від типу двигуна (типу палива) та інших параметрів. Проте коефіцієнти, що використовуються в даному методі, носять емпіричний характер, а співвідношення, отримані емпіричним шляхом, не дозволяють враховувати деякі особливості, зокрема наявність і використання апріорної інформації про місцевість і характер впливу окремих чинників або їх взаємний вплив на якість визначення рівня забруднень.

Для цього потрібне використання більш точної функціональної моделі на основі теорії статистичних рішень з урахуванням сезонних змін і інших особливостей аналізу місцевості. При цьому необхідне комплексування прескриптивної та дескриптивної моделей для об'єднання апріорної інформації, отриманої контактними і дистанційними методами зондування земної поверхні на заданій ділянці місцевості. Побудова такої функціональної моделі повинна бути заснована на алгебрі нечіткої логіки, що дозволяє аналізувати нечіткі ситуації і давати кількісні оцінки відповідним комбінаціям даних чинників впливу. 
Наприклад, аналіз та урахування лише декількох чинників, таких як інтенсивність руху та його швидкість, крутизна схилу, кількість опадів, наявність лісосмуги, дає суттєві переваги при кількісній оцінці концентрації викидів автомобільного транспорту уздовж автошляхів. Розглянемо механізм урахування та взаємного впливу вищевказаних чинників на показник, що оцінює рівень забруднень в даній місцевості.

Аналізуючи проблему екологічного забруднення викидами автотранспорту уздовж доріг, торкаємось системи, що містить велике число змінних, які взаємодіють один з одним, реагуючих на зміни кожної іншої змінної, які представляються у вигляді причинно-наслідкових відносин, що можна виразити у вигляді графових моделей взаємодії (рис. 2). Використання нечіткої логіки як модель складної системи засноване на наступному. Найістотніші процеси для даної проблеми зображуємо вершинами графа. Від вершини $u$ до вершини $v$ проводиться дуга, якщо зміна $u$ надає безпосередню істотну дію на $v$ і дана дуга має знак «плюс», якщо дія $\epsilon$ «посиленням» (за інших рівних умов збільшення $u$ приводить до збільшення $v$ і зменшення $u$-до зменшення $v$ ), i знак «мінус», - якщо дія викликає «гальмування» (за інших рівних умов збільшення $u$ приводить до зменшення $V$ і зменшення $u$-до збільшення $v$ ) [19].

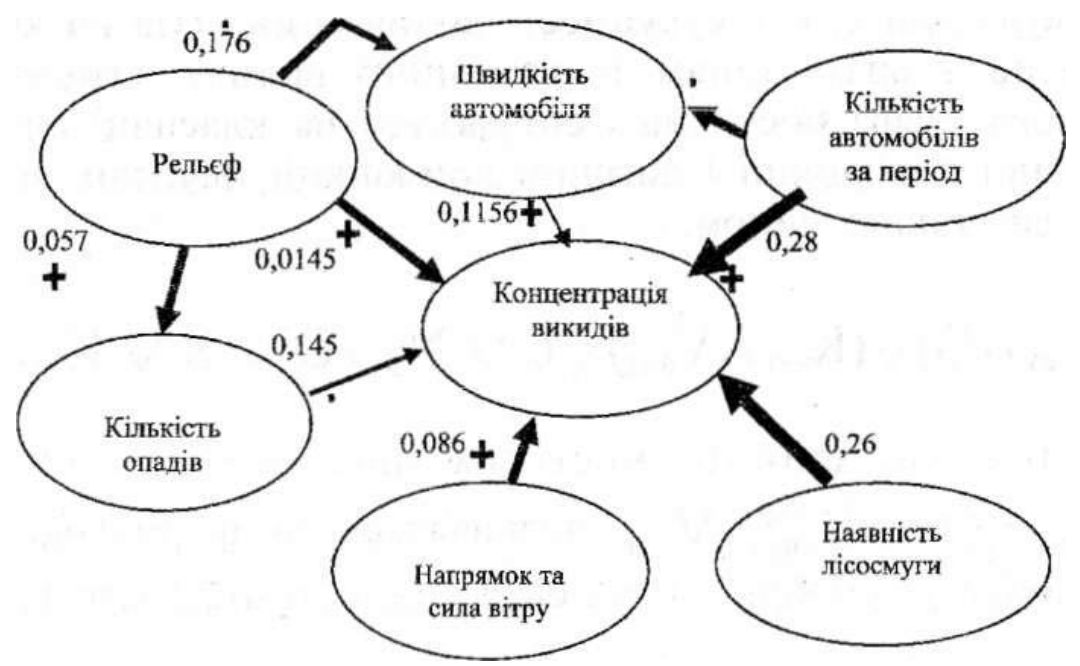

Рис. 2 - Базова структура моделі обліку забруднень автомобільним транспортом уздовж доріг

Для побудованого графа посилень, що показує взаємний вплив перерахованих вище чинників один на одного і впливи цих же чинників на кількість викидів солей свинцю $P_{p b}$, необхідно встановити значення вагових коефіцієнтів ступеня впливу відповідно до алгоритму Флойда. Ці коефіцієнти приймуть наступні значення:

1. При впливі чинника на кількість забруднень:

Рельєф (R) - 0,0145

Викиди автотранспорту $\left(\mathrm{K}_{\text {авт }}\right)-0,28$

Опади $(\mathrm{O})-0,145$

Biтер $\left(\mathrm{N}_{\mathrm{B}}\right)-0,086$

Наявність лісосмуги (L) - 0,26

Швидкість автотранспорту $\left(\mathrm{V}_{\text {авт }}\right)-0,1156$. 
2. При взаємному впливі чинників:

Рельєфу на швидкість автотранспорту $\left(\mathrm{R} \bullet \mathrm{V}_{\text {авт }}\right)-0,176$

Рельєфу і опадів $(\mathrm{R} \bullet \mathrm{O})-0,057$

Викиди автотранспорту і швидкість автотранспорту $\left(\mathrm{K}_{\text {авт }} \bullet \mathrm{V}_{\text {авт }}\right)-0,057$.

Отримані значення вагових коефіцієнтів використовуються в подальших розрахунках, зокрема для обчислення консеквента (висновка сумісних логічних висловів) при операціях логічної диз'юнкції і кон'юнкції при визначенні інтегрального показника сукупності комбінаторних множин для побудови подальшої функціональної залежності, що визначає значення функції приналежності [13].

Таким чином, середнє значення інтегрального показника сукупності комбінаторних множин дорівнює 1,87 .

Емпіричним шляхом, 3 використанням відповідних статистичних даних були визначені функціональні залежності впливу кожного з чинників на рівень забруднення: інтенсивності руху на даній дорозі; вірогідності проїзду даної марки машини; вмісту добавки свинцю в паливі, вживаному на автомобілі даного типу; вірогідності використовування даної марки бензину.

Маршрути проводились для картографування територій ландшафтів на основі візуальних спостережень, для складання карт забруднення грунтів, поверхневих і грунтових вод, атмосферного повітря та порушень геологічного середовища вздовж автомобільних шляхів. Під час маршрутів, крім польового картування окремих компонентів урбоекосистеми, відбирались проби (зразки) грунтів, поверхневих і грунтових вод, атмосферного повітря і рослинності. Всього було відібрано 105 проб грунтів, 38 проб поверхневих і 37 проб грунтових вод і 30 проб рослинності (рис. 3).

Всі проби були проаналізовані різними методами у Центральній біохімічній лабораторії м. Київ.

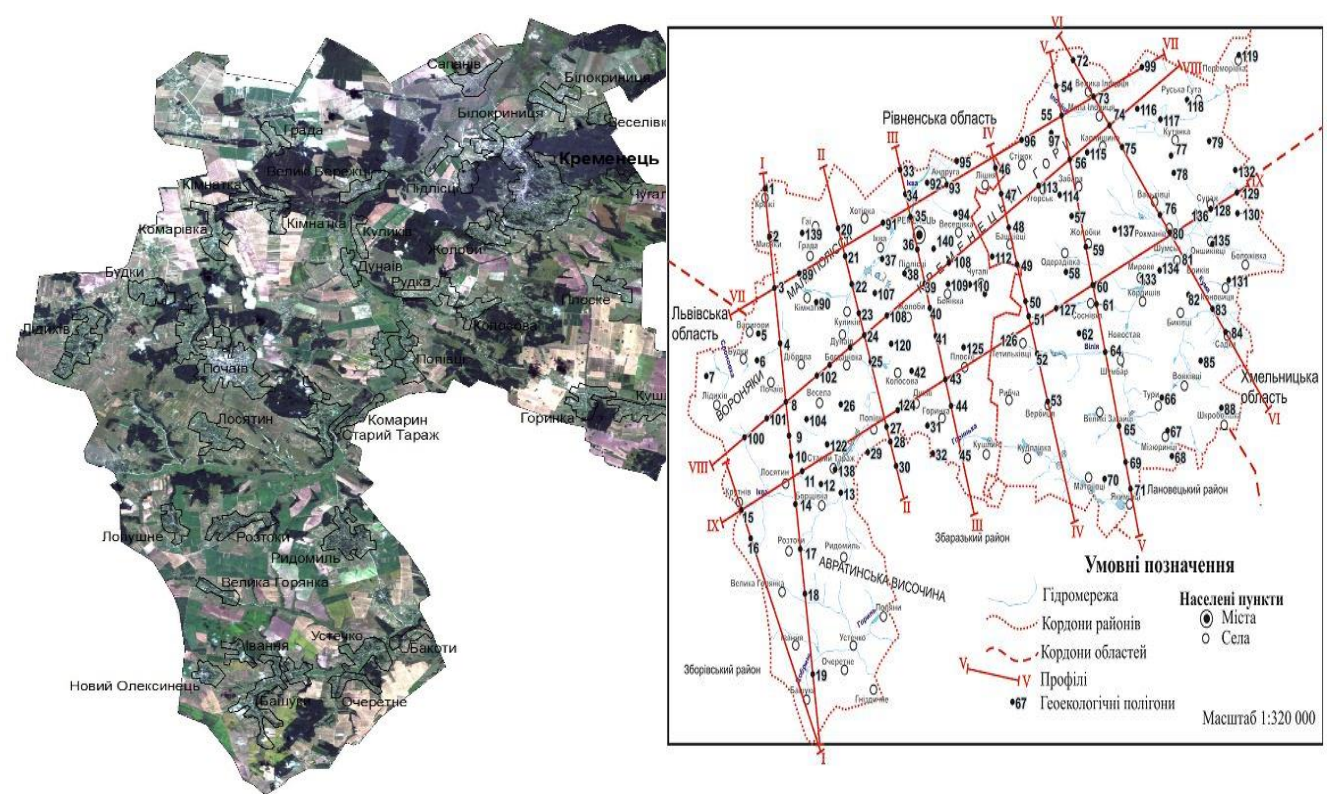

Рис. 3 - Космічний знімок з супутника Landsat 5 та картосхема відбору проб Кременецького району 
В результаті були виготовлені еколого-техногеохімічні карти грунтів, поверхневих і грунтових вод, атмосферного повітря і рослинності (рис. 4).

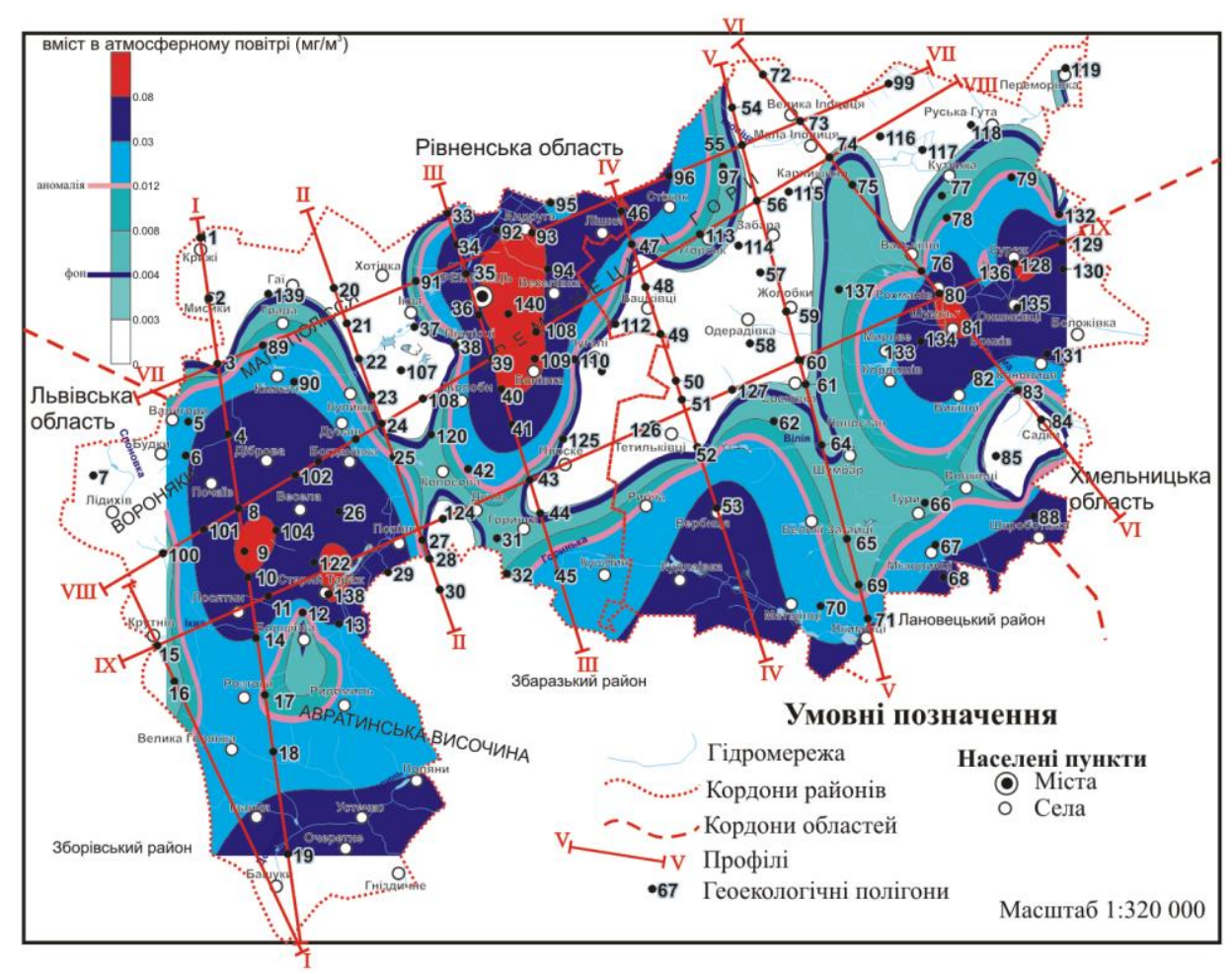

Рис. 4 - Картосхема розповсюдження вуглекислого газу $\left(\mathrm{CO}_{2}\right)$ в атмосферному повітрі

Характерною рисою більшості сучасних міст і сіл, в тому числі i Тернопільщини, є перетворення первинних природних ландшафтів у нові природно-техногенні геоекосистеми та досить істотна зміна екологічного стану основних компонентів урбоекосистеми [4, 5]. На екологічній карті відображені просторові особливості змін геологічного середовища, геофізичних полів, рельєфу, поверхневих і грунтових вод, атмосферного повітря, грунтового і рослинного покривів, стану здоров'я населення та об'єктів техносфери, яка істотно впливає на всі попередні складові природного середовища. Карта дозволила оцінити наскільки змінені первинні ландшафти, які кількісні і якісні зміни відбулись у всіх компонентах довкілля і як ці трансформації вплинули на людину.

\section{Висновки}

Розроблена методологія є одним зі способів видачі попереднього прогнозу розповсюдження забруднень з урахуванням збурюючих чинників за наявності апріорних даних. В даній методології враховуються сукупність чинників впливу на рівень концентрації забруднень і отримані емпіричним шляхом функціональні залежності впливу кожної зі збурюючих складових на рівень забруднення. Побудована модель взаємодії встановлених чинників у вигляді графа взаємодії характеризує причинно-наслідкові відносини. 


\section{СПИСОК ЛІТЕРАТУРИ}

1. Красовський Г.Я., Трофимчук О.М., Крета Д.Л., Клименко В.І., Пономаренко І.Г., Суходубов О.О. Синтез картографічних моделей забруднення земель техногенним пилом з використанням космічних знімків // Екологія і ресурси. - К.: ІПНБ, 2005. №12. - C. 37-55.

2. Адаменко О.М., Міщенко Л.В. Екологічний аудит територій: Підручник / О.М. Адаменко, Л.В. Міщенко. - Івано-Франківськ: ФАКЕЛ, 2000. - 241 с.

3. Гуцуляк В.М. Ландшафтна екологія. Геохімічний аспект: Навч. Посіб / В.М. Гуцуляк. - Чернівці: Рута, 2002. - 272 с.

4. Триснюк В.М. Екологія Гусятинського району / В.М. Триснюк. - Тернопіль. Тернограф. 2004. -219 с.

5. Рудько Г.І., Назаренко М.В. Геоінформаційні технології в надрокористуванні / Г.І. Рудько, М.В. Назаренко - К.: «Академпрес», 2011. - 336 с.

6. Данилко В.К. Забруднення атмосферного повітря автомобільним транспортом: підходи до стратегічного визначення // Статистика України. - К., 2003. - № 4. - С. 9-11. 7. Бутенко О.С. Комплексный подход к дешифрированию снимков по данным космического мониторинга / О.С. Бутенко, С.И. Березина, Г.Я. Красовский. Екологічна безпека та природокористування: 36. наук. праць / М-во освіти і науки України, К., .2008. - Вип. 1. - С. 23-41.

8. Trysnyuk, V., Okhariev, V., Trysnyuk, T., Zorina, O., Kurylo, A., Radlowska, C. (2019). Improving the algorithm of satellite images landscape interpretation. In 18th International Conference Geoinformatics - Theoretical and Applied Aspects, vol. 2019, p. 1-5.

http://www.earthdoc.org/publication/publicationdetails/?publication=98507

DOI: $10.3997 / 2214-4609.201902084$

9. Trysnyuk, V.M., Smetanin K.V., Trysnyuk T.V., Holowan Y.V., Kashchishin O.L., Radlowska K.O. (2019). The improvement of the system of ecological monitoring of the environment through the application of remotely piloted aircraft systems. XIII International Scientific Conference - "Monitoring of Geological Processes and Ecological Condition of the Environment", Extended Abstracts.

http://www.earthdoc.org/publication/publicationdetails/?publication $=10050$

10. Триснюк В.М. Аерогеолокаційний екологічний контроль. / В.М. Триснюк, A.В. Павлишин, А.В. Курило // MONOGRAFIA POKONFERENCYJNA. Warszawa, 2020. C. 46.

11. Триснюк В.М. Екологічна безпека телекомунікаційних систем та технологій / В.М. Триснюк, К.В. Сметанін, А.В. Курило, Ю.М. Голован, Т.В. Триснюк // Ризики нестабільності: безпека i управління. Міждисциплінарна науково-практична конференція. Київ. 16 березня 2018 р. - С. 49-52.

12. Okhariev, V., Trysnyuk, V. [2019] Environmental aspects of Ukrainian energy sector in connection with transition to low-carbon development. Conference - Monitoring of Geological Processes and Ecological Condition of the Environment.

13. Trofymchuk O., Myrontsov M., Okhariev V., Anpilova Y., Trysnyuk V. [2021] Transdisciplinary analytical system for support the environmental researches. Systems, decision and control in energy II. Studies in systems, decision and control. Springer. Cham. 14. Trofymchuk, O., Lebid, O., et al. (2019). Dynamic certification of landslide protection structures in a seismically hazardous region of Ukraine: experimental and analytical research. Earthquake geotechnical engineering for protection and development of environment and constructions. In: Silvestri F., Moraci N. (eds.). Proc. of the VII ICEGE 7th International Conference on Earthquake Geotechnical Engineering, Rome, Italy, 17-20 June 2019, 5337-5344. 15. Макарова А.И. Ореолы рассеяния тяжелых металлов на территории, прилегающей к автомагистрали. / А.И. Макарова, С.Ф. Полунин, Н.П. Ильин, Ф.И. Славин // Гигиена и санитария, 1993, № 7. - С. 63-64.

16. Greben, S., Trofymchuk, O., Trysnyuk, V., Krasovskiy, G. [2020] Interpretation of remote sensing data for ecological tasks. IEEE Ukrainian Microwave Week (UkrMW): 10th 
International Kharkiv Symposium on Physics and Engineering of Microwaves, Millimeter and Submillimeter Waves (21-25 September, Kharkiv, Ukraine), Volume 3, P. 772-776.

17. Trofymchuk, O., Okhariev V., Trysnyuk V. [2019] Environmental security management of geosystems. Conference Proceedings. 18th International Conference on Geoinformatics Theoretical and Applied Aspects.

18. Триснюк В.М. Екологічна безпека Карпатського регіону в умовах техногенного пилового забруднення атмосферного повітря / В.М. Триснюк, В.О. Шумейко, Т.В. Триснюк, А.В. Курило, Ю.М. Голован, В.В. Мирончук // Збірник наукових праць «Системи управління, навігації та зв'язку». Полтавський національний технічний університет імені Юрія Кондратюка. Випуск 1(59) 2020 р. С. 127-131.

19. Триснюк Т.В., Підвищення рівня екологічної безпеки об'єктів природнозаповідного фонду / Т.В. Триснюк, Ю.М. Голован, А.В. Курило // Сучасні інформаційні технології управління екологічною безпекою, природокористуванням, заходами в надзвичайних ситуаціях: Колективна монографія: XVII Міжнародна науково-практична конференція. Інститут телекомунікацій i глобального інформаційного простору НАНУ. Київ. 25-26 вересня 2018 р. - С. 213-214.

Стаття надійшла до редакиії 25.01.2021 і прийнята до друку після рещензування 04.05.2021

\section{REFERENCES}

1. Krasovsky, G.Ya., Trofimchuk, O.M., Kreta, D.L., Klimenko, V.I., Ponomarenko, I.G., \& Sukhodubov, O.O. (2005). Synthesis of cartographic models of land pollution by man-made dust using space images. Ecology and resources, 12, 37-55 (in Ukrainian).

2. Adamenko, O.M., \& Mishchenko, L.B. (2000). Ecological audit of territories: Textbook. Ivano-Frankivsk: FAKEL (in Ukrainian).

3. Gutsulyak, V.M. (2002). Landscape ecology. Geochemical aspect: Textbook. Chernivtsi: Ruta (in Ukrainian).

4. Trysnyuk, V.M. (2004). Ecology of Husiatyn district. Ternopil: Ternograph (in Ukrainian). 5. Rudko, G.I, \& Nazarenko, M.V. (2011). Geoinformation technologies in subsoil use. Kyiv: "Academpress" (in Ukrainian).

6. Danilko, V.K. (2003). Atmospheric air pollution by road transport: approaches to strategic determination. Statistics of Ukraine, 4, 9-11 (in Ukrainian).

7. Butenko, O.S., Berezina, S.I., \& Krasovsky, G.Ya. (2008). A comprehensive approach to decoding images based on space monitoring data. Environmental safety and nature resourses, 1, 23-41 (in Russian).

8. Trysnyuk, V., Okhariev, V., Trysnyuk, T., Zorina, O., Kurylo, A., \& Radlowska, C. (2019). Improving the algorithm of satellite images landscape interpretation. In 18th International Conference Geoinformatics - Theoretical and Applied Aspects. (Vol. 2019, pp. 1-5). http://www.earthdoc.org/publication/publicationdetails/?publication=98507

DOI: $10.3997 / 2214-4609.201902084$

9. Trysnyuk, V.M., Smetanin, K.V., Trysnyuk, T.V., Holowan, Y.V., Kashchishin, O.L., \& Radlowska, K.O. (2019). The improvement of the system of ecological monitoring of the environment through the application of remotely piloted aircraft systems. In XIII International Scientific Conference - "Monitoring of Geological Processes and Ecological Condition of the Environment", Extended Abstracts.

http://www.earthdoc.org/publication/publicationdetails/?publication $=10050$

10. Trysnyuk, V.M., Pavlishin, A.V., \& Kurilo, A.V. (2020). Aerogelocation ecological control. Warszawa.

11. Trysnyuk, V.M., Smetanin, K.V., Kurylo, A.V., Holovan, Yu.M., \& Trysnyuk, T.V. (2018). Ecological safety of telecommunication systems and technologies. In Risks of instability: security and management. Interdisciplinary scientific-practical conference. (pp. 49-52). Kyiv (in Ukrainian). 
12. Okhariev, V., \& Trysnyuk, V. (2019). Environmental aspects of Ukrainian energy sector in connection with transition to low-carbon development. In Conference - Monitoring of Geological Processes and Ecological Condition of the Environment.

13. Trofymchuk, O., Myrontsov, M., Okhariev, V., Anpilova, Y., \& Trysnyuk, V. (2021). Transdisciplinary analytical system for support the environmental researches. In Systems, decision and control in energy II. Studies in systems, decision and control. Springer, Cham. 14. Trofymchuk, O., Lebid, O., et al. (2019). Dynamic certification of landslide protection structures in a seismically hazardous region of Ukraine: experimental and analytical research. Earthquake geotechnical engineering for protection and development of environment and constructions. In: Silvestri F., Moraci N. (eds.). Proc. of the VII ICEGE 7th International Conference on Earthquake Geotechnical Engineering, Rome, Italy, 17-20 June 2019, 5337-5344.

15. Makarova, A.I., Polunin, S.F., Ilyin, N.P., \& Slavin, F.I. (1993). Scattering halos of heavy metals in the area adjacent to the highway. Hygiene and Sanitation, 7, 63-64 (in Russian).

16. Greben, S., Trofymchuk, O., Trysnyuk, V., \& Krasovskiy, G. (2020). Interpretation of remote sensing data for ecological tasks. In IEEE Ukrainian Microwave Week (UkrMW): 10th International Kharkiv Symposium on Physics and Engineering of Microwaves, Millimeter and Submillimeter Waves (Vol. 3, pp. 772-776). Kharkiv, Ukraine.

17. Trofymchuk, O., Okhariev, V., \& Trysnyuk, V. (2019). Environmental security management of geosystems. In 18th International Conference on Geoinformatics Theoretical and Applied Aspects.

18. Trysnyuk, V.M., Shumeiko, V.O., Trysnyuk, T.V., Kurylo, A.V., \& Golovan, Yu.M. (2020). Ecological safety of the Carpathian region in the conditions of technogenic dust pollution atmospheric air. Control, Navigation and Communication Systems. Academic Journal, 1 (59), 127-131. https://doi.org/https://doi.org/10.26906/SUNZ.2020.1.127 (in Ukrainian).

19. Trysnyuk, T.V. Golovan, Yu.M., \& Kurilo, A.V. (2018). Increasing the level of environmental safety of nature reserves. In Modern information technologies for environmental safety management, nature management, emergency measures: Collective monograph: XVII International scientific-practical conference (pp. 213-214). Kyiv: Institute of Telecommunications and Global Information Space of NASU (in Ukrainian).

The article was received 25.01.2021 and was accepted after revision 04.05.2021

\section{Триснюк Василь Миколайович}

доктор технічних наук, старший науковий співробітник, завідувач відділу досліджень навколишнього середовища Інституту телекомунікацій і глобального інформаційного простору НАН України

Адреса робоча: 03186, Київ, Чоколівський бульвар, 13

ORCID 0000-0001-9920-4879, e-mail: trysnyuk@ukr.net

\section{Шумейко Віктор Олександрович}

кандидат технічних наук, старший науковий співробітник відділу досліджень навколишнього середовища Інституту телекомунікацій і глобального інформаційного простору НАН України

Адреса робоча: 03186, Київ, Чоколівський бульвар, 13

ORCID 0000-0002-0285-4566, e-mail: shym1983@ukr.net

\section{Голован Юрій Миронович}

аспірант Інституту телекомунікацій і глобального інформаційного простору НАН України

Адреса робоча: 03186, Київ, Чоколівський бульвар, 13

ORCID 0000-0001-7050-9310,e-mail: dirrecta@gmail.com 